\title{
Effect of reclaimed municipal wastewater irrigation on greenhouse soil mineral nitrogen dynamic and fruit quality of tomato*
}

\author{
Ping $\mathrm{Li}^{\dagger}$ \\ Institute of Water Resources and Hydro-electric Engineering, \\ XI'AN University of Technology, \\ Xi'an, 710048, P.R. China \\ E-mail: firilp@163.com \\ www.xaut.edu.cn \\ Xue-Bin Qi, Zhen-Jie Du, Chao Hu and Wei Guo \\ Farmland Irrigation Research Institute of CAAS, \\ Key Laboratory of High-efficient and Safe Utilization \\ of Agriculture Water Resources of CAAS, $380^{\text {th }}$ Hongli avenue \\ Xinxiang, 453002, P.R. China \\ E-mail:qxb6301@sina.cn
}

\begin{abstract}
To examine the effects of nitrogen and reclaimed municipal wastewater(RMW) irrigation on fruit quality of greenhouse tomato and soil nitrogen utilization, field experiments were carried out. Root-layer mineral nitrogen, total nitrogen, tomato yield, nitrogen in fruit, partial factor productivity from applied $\mathrm{N}$, apparent $\mathrm{N}$ loss, nitrogen supplying capacity and fruit quality(flavor quality, nutritional quality) were analyzed. The results indicated that RMW irrigation leaded to an average of $1.72-40.39 \%$ increase in mineral nitrogen and total nitrogen of rhizosphere soil in $1^{\text {st }}, 2^{\text {nd }}$ and $4^{\text {th }}$ cluster fruit expanding stage. Compared with CK, nitrogen in fruit, partial factor productivity from applied $\mathrm{N}$ and nitrogen supplying capacity of RMW irrigation were obvious increased. Furthermore, compared with CK, nutritional quality of tomato fruits were improved significantly. Maintaining soil fertility, the yield and nutritional quality of fruits were therefore notable improved under RMW irrigation, and which was an effectively management strategy of soil sustainable production and alleviating soil environment.
\end{abstract}

Keywords: Reclaimed Municipal Wastewater Irrigation; Greenhouse Tomato; Partial Factor Productivity from Applied N; Nitrogen Supplying Capacity; Nutritional Quality.

\footnotetext{
* This work is supported by the Agricultural Science and Technology Innovation Program of Chinese Academy of Agricultural Sciences (CAAS-ASTIP-FIRI-03), the National Natural Science Foundation of China $(51009141,51679241)$ and the National 863 Plans Project of China (2012 AA101404)
} 


\section{Introduction}

China is a serious shortage of water resources in the world, particularly in agricultural water shortage, which greatly restricted agricultural sustainable development and food security. At the same time, there are a lot of low quality water didn't be used of safe, effective and standard in China. According to the China's water resources in 2014, the national wastewater emissions was 77.1 billion $\mathrm{m}^{3}$, and municipal wastewater emissions was 43.8 billion $\mathrm{m}^{3}$, accounted for $56.81 \%$. In order to ensure agricultural production, low quality water was spontaneous used for irrigation in the arid and semi-arid area. Reclaimed municipal wastewater was mainly irrigation for agriculture, Australia's Werribee farm irrigated with reclaimed wastewater since 1897(McPherson, 1979), 42\% of the reclaimed water consumption was used for agricultural irrigation(Valentina, 2005). Crop area irrigated with reclaimed wastewater in China was increasing year by year, such as reclaimed water consumption of Beijing was 680 million $\mathrm{m}^{3}$ in 2010, $44.11 \%$ of the reclaimed water consumption was used for agricultural irrigation(Lyuet al. 2016). Compared with sewage quality, the quality of reclaimed wastewater has been improved, but still contained high concentration of organics, nitrogen, phosphorus and microbe, so there were three aspects of the problem should be emphasis. First the effect of reclaimed wastewater irrigation on soil ecological environment should be focused, soil porosity could be reduced and then soil water retention and hydraulic conductivity was decreased because of reclaimed wastewater irrigation, resulting in a decline in soil sustainable production capacity(Aiello, 2007). Then the effect of reclaimed wastewater irrigation on soil acidification should be followed. According to the former research, China mainly farmland soil acidification was obvious since 1980s(Guo, 2010), furthermore, long-term excessive nitrogen fertilization was the leading cause of farmland soil acidification accelerated(Chen et al, 2016), especially high concentration nitrogen in reclaimed wastewater from municipal sewage, soil acidification might be aggravated under reclaimed wastewater irrigation with traditional nutrient management. And the effect of reclaimed wastewater irrigation on fruit quality should be cared. Nitrogen supply too much could lead to excessive nitrogen accumulation in tomato plants, which decreased the taste of the fruit, content of sugar and starch(Shahalamet al. 1998). At present the research about reclaimed wastewater irrigation on greenhouse tomato focus on nitrogen use efficiency(Fan et al. 2012), nutrient management technology(Grizzettiet al. 2015), N-expert management system(Chen et al. 2006), soil nitrogen supplying capacity(Clawsonet al. 2011), tomato growth and quality(Zhao et al. 2011), salt stress(Yao et al. 2008). However, the mechanisms involved in reclaimed 
wastewater irrigation and its effect on soil nitrogen recycle remain poorly understood.

In this work, attempt was made to discover the dynamic of soil nitrogen forms under reclaimed municipal wastewater irrigation, and then refined the mechanisms involved in reclaimed wastewater irrigation effect on soil nitrogen recycle.

\section{Materials and Methods}

\subsection{Study site}

Field experiments were carried at the Agriculture Water and Soil Environmental Field Science Research Station, Chinese Academy of Agricultural Science, Xinxiang city, Henan province, China (latitude $35^{\circ} 15^{\prime} 09^{\prime \prime} \mathrm{N}$, longitude $113^{\circ} 55^{\prime} 05^{\prime \prime} \mathrm{E}$, and altitude $73.2 \mathrm{~m}$ ). Soil physical and chemical properties were shown in Table 1, soil texture classification according to the international soil texture classification standard.

Table 1. The basic physical and chemical properties of soil in experiment site.

\begin{tabular}{|c|c|c|c|c|c|c|c|c|c|}
\hline \multirow{2}{*}{$\begin{array}{c}\text { Soil } \\
\text { depth } \\
(\mathrm{cm}) \\
\end{array}$} & \multicolumn{3}{|c|}{ The percentage of particle size $(\%)$} & \multirow[b]{2}{*}{$\mathrm{pH}$} & \multirow{2}{*}{$\begin{array}{c}\text { Total N } \\
(\mathrm{g} / \mathrm{kg})\end{array}$} & \multirow{2}{*}{$\begin{array}{c}\text { Total P } \\
(\mathrm{g} / \mathrm{kg})\end{array}$} & \multirow{2}{*}{$\begin{array}{l}\text { Org. } \\
\text { matter } \\
(\mathrm{g} / \mathrm{kg}) \\
\end{array}$} & \multirow[b]{2}{*}{ Texture } & \multirow{2}{*}{$\begin{array}{c}\text { Bulk } \\
\text { density } \\
\left(\mathrm{g} / \mathrm{cm}^{3}\right)\end{array}$} \\
\hline & $\begin{array}{c}2-0.02 \\
\mathrm{~mm}\end{array}$ & $\begin{array}{c}0.02-0.002 \\
\mathrm{~mm}\end{array}$ & $\begin{array}{c}<0.002 \\
\mathrm{~mm}\end{array}$ & & & & & & \\
\hline $0-20$ & 27.88 & 54.77 & 17.35 & 8.00 & 0.95 & 1.16 & 19.90 & $\begin{array}{l}\text { Silt clay } \\
\text { loam }\end{array}$ & 1.40 \\
\hline $20-40$ & 24.99 & 58.29 & 16.72 & 8.05 & 0.46 & 0.58 & 9.90 & $\begin{array}{l}\text { Silt clay } \\
\text { loam }\end{array}$ & 1.42 \\
\hline $40-60$ & 26.57 & 57.06 & 16.37 & 8.10 & 0.39 & 0.52 & 8.60 & $\begin{array}{l}\text { Silt clay } \\
\text { loam }\end{array}$ & 1.44 \\
\hline $60-80$ & 30.22 & 53.18 & 16.60 & 8.00 & 0.26 & 0.36 & 8.00 & $\begin{array}{l}\text { Silt clay } \\
\text { loam }\end{array}$ & 1.42 \\
\hline $80-100$ & 22.04 & 62.44 & 15.52 & 7.90 & 0.24 & 0.30 & 7.30 & Silt loam & 1.49 \\
\hline
\end{tabular}

\subsection{Experiment design and measuring items}

The field trial was a fully randomized design with three replicates of five treatments (ReN1, ReN2, ReN3, ReN4 and CK) using RMW and tap water irrigation with subsurface drip irrigation systems. The ReN1, ReN2, ReN3, ReN4 and CK treatments consisted of nitrogen topdressing as 90, 72, 63, 45 and $90 \mathrm{~kg} / \mathrm{hm}^{2}$, respectively. Base fertilizers included dried chicken manure, nitrogen, phosphorus, potassium fertilizers, rated at 8 000, 180, 180 and 180 $\mathrm{kg} / \mathrm{hm} 2$, respectively. Plots of RMW treatments were irrigated two times with tap water during seedling stage, and with RMW after the blooming and fruit setting period. Furthermore, plots of CK treatment were irrigated with tap water during the growth span of tomato. The traditional strip planting regime for 
tomatoes was used, which had a border width $\times$ interval of $1.0 \times 0.5 \mathrm{~m}$, a row spacing of $0.3 \mathrm{~m}$, a line spacing of $0.75 \mathrm{~m}$ and a planting density of 45000 plants per hectare. Tomato plants were transplanted on March 26, 2015 and tomatoes were harvested on July 14, 2015. Tomato plants were evaluated at the developmental stages consisting of 5 clusters and topdressing with nitrogen was performed at the 1st, 2nd and 4th cluster fruit expanding stage. Other management practices during the whole growth season were completely standard.

The RMW for irrigation was taken from the Luotuo Wan water source plant in Xinxiang city Henan province, under treatment process of anaerobic-anoxicoxic denitrification biofilter and ozone oxidation. Basic properties of RMW and tap water used were listed in the Table 2.

Table 2. The ingredients of reclaimed municipal wastewater and tap water irrigated.

\begin{tabular}{|c|c|c|c|c|c|}
\hline Monitoring items & $\begin{array}{l}\text { Nitrate/ } \\
\left(\mathrm{mg} \cdot \mathrm{L}^{-1}\right)\end{array}$ & $\begin{array}{l}\text { Ammonium } \\
/\left(\mathrm{mg} \cdot \mathrm{L}^{-1}\right)\end{array}$ & $\begin{array}{l}\text { Total nitrogen } \\
/\left(\mathrm{mg} \cdot \mathrm{L}^{-1}\right)\end{array}$ & $\begin{array}{l}\text { Total } \\
\text { phosphorus/ } \\
\left(\mathrm{m} \cdot \mathrm{L}^{-1}\right)\end{array}$ & $\begin{array}{l}\text { Copper/ } \\
\left(\mathrm{mg} \cdot \mathrm{L}^{-1}\right)\end{array}$ \\
\hline Tap water & 2.58 & 0.70 & 2.64 & 0.56 & 0.01 \\
\hline RMW & 27.28 & 17.08 & 26.40 & 3.14 & 0.02 \\
\hline The limit values ${ }^{\mathrm{c}}$ & - & - & - & - & 1.0 \\
\hline Monitoring items & $\begin{array}{l}\text { Cadmium/ } \\
(\mu \mathrm{g} \cdot \mathrm{L}-1)\end{array}$ & $\begin{array}{l}\text { Chromium/ } \\
(\mu \mathrm{g} \cdot \mathrm{L}-1)\end{array}$ & $\begin{array}{l}\text { CODMna/ } \\
(\mathrm{mg} \cdot \mathrm{L}-1)\end{array}$ & $\mathrm{pH}$ & $\begin{array}{c}\text { TDSb } \\
/(\mathrm{g} \cdot \mathrm{L}-1)\end{array}$ \\
\hline Tap water & 0.71 & 6.48 & 9.82 & 7.51 & 0.90 \\
\hline RMW & 3.35 & 19.60 & 23.63 & 7.76 & 1.23 \\
\hline The limit valuesc & 10 & 100 & 60 & $5.5-8.5$ & 1.00 \\
\hline \multicolumn{6}{|c|}{$\begin{array}{l}\text { Note: } \\
\text { ac }{ }^{\mathrm{C}} \mathrm{D}_{\mathrm{Mn}} \text { represented chemical oxygen demand. } \\
{ }^{\mathrm{b}} \mathrm{TDS} \text { represented total dissolved salt. }\end{array}$} \\
\hline
\end{tabular}

Soil samples were collected with a standard $3.5 \mathrm{~cm} \varnothing$ soil auger at tomato transplanting and harvest stages, 5 samples were collected per plot and stored at room temperature before analyzing for $\mathrm{NO}_{3}-\mathrm{N}, \mathrm{NH}_{4}-\mathrm{N}$, total $\mathrm{N}$, Total $\mathrm{P}, \mathrm{KpH}$ and ECe. Three plant samples per plot were taken at post-harvest period, samples were analyzed for $\mathrm{NO}_{3}-\mathrm{N}, \mathrm{NH}_{4}-\mathrm{N}$, total $\mathrm{N}$, available $\mathrm{P}$ and $\mathrm{K}$ in root, stem, leaf, and then five fresh maturity fruits were taken during $1^{\text {st }}$ cluster stage, $2^{\text {nd }}$ cluster stage, $3^{\text {rd }}$ cluster stage, $4^{\text {th }}$ cluster stage and $5^{\text {th }}$ cluster stage, samples were analyzed for vitamin $\mathrm{C}$, organic acid, protein and soluble sugar.

Analysis of variance (ANOVA) was performed with one-way ANOVA using DPS14.50 software. Treatments were compared for significant differences ( $\mathrm{p}<0.05$ level) using DMRT. 


\section{Results and Discussion}

\subsection{Mineral nitrogen dynamic during the tomato whole growth stage with RMW irrigation}

The rhizosphere soil mineral nitrogen content of ReN1, ReN2, ReN3, ReN4 and CK was lower than that of bulk soil by 27.59, 10.47, 10.89, 0.96 and 19.26\% in the 1 st cluster fruit expanding stage, and by 15.82, 12.63, 11.66, 1.33 and $12.69 \%$ in the 2ndcluster fruit expanding stage, and by 10.04, 10.92, 10.75, 1.91 and $31.98 \%$ in the 4thcluster fruit expanding stage, and by $18.27,10.29,10.90,8.90$ and $25.99 \%$, respectively in the late growth stage. In comparison with CK, ReN2 leaded to an average of 40.39, 5.42 and $10.63 \%$, respectively, increase in mineral nitrogen of rhizosphere soil in 1st, 2nd and 4th cluster fruit expanding stage (Table 3). After post-harvest, residual mineral nitrogen in the 0 - 10, 10 20 and $40-60 \mathrm{~cm}$ soil layer of ReN2 was significantly lower than that of CK, differing by $18.90,22.90$ and $10.11 \%$, respectively(Figure 1). Mineral nitrogen consumption in the $0-30 \mathrm{~cm}$ root soil layer could be therefore used to evaluate soil nitrogen for biological effectiveness and root layer nitrogen as supplying capacity (Palese et al. 2009, Chen et al. 2012). Mineral nitrogen content of ReN2 and ReN3 in the $0-30 \mathrm{~cm}$ root soil layer was maintained above $40 \mathrm{mg} / \mathrm{kg}$, which was key evidence because nitrogen supplying capacity under RMW irrigation and suitable topdressing (Zhao et al. 2010). Post-harvest mineral nitrogen residual in the $10-20$ and $20-30 \mathrm{~cm}$ layers of ReN2 and ReN3 was significantly higher than that of ReN1 and CK, however, total nitrogen residual in the $30-40 \mathrm{~cm}$ and $40-60 \mathrm{~cm}$ layers of ReN1 was significantly higher than that of ReN2 and ReN3, which indicated that nitrogen accumulation in the lower soil was coincident with the excessive application of topdressing with RMW irrigation. The growth of tomato acquired plenty of mineral nutrients that came mainly from the rhizosphere soil (Pereira et al. 2011), however, the differences in mineral content between the rhizosphere and bulk soil suggested that the mineral nutrients of bulk soil migrated into the rhizosphere. Thus, the mineral nitrogen content between rhizosphere and bulk soil were not significantly different during the tomato post-harvest stage. 
Table 3. Changes of soil mineral nitrogen content of different growth stage under different topdressing amount of $\mathrm{N}$ with RMW and tap water irrigation in the rhizosphere and bulk soil.

\begin{tabular}{|c|c|c|c|c|c|}
\hline \multirow[b]{2}{*}{$\begin{array}{c}\text { Soil } \\
\text { division }\end{array}$} & \multirow[b]{2}{*}{ Treatments } & \multicolumn{4}{|c|}{ mineral nitrogen content $(\mathrm{mg} / \mathrm{kg})$} \\
\hline & & $\begin{array}{c}1^{\text {st }} \text { cluster } \\
\text { expanding stage }\end{array}$ & $\begin{array}{c}2^{\text {nd }} \text { cluster } \\
\text { expanding stage }\end{array}$ & $\begin{array}{c}4^{\text {th }} \text { cluster } \\
\text { expanding stage }\end{array}$ & $\begin{array}{c}\text { Post- } \\
\text { harvest }\end{array}$ \\
\hline \multirow{5}{*}{ Rhizosphere soil } & ReN1 & 73.1ab & $93.0 \mathrm{~cd}$ & $52.5 \mathrm{~b}$ & $51.4 \mathrm{~b}$ \\
\hline & ReN2 & $77.4 \mathrm{a}$ & $104.3 \mathrm{bc}$ & $51.6 \mathrm{~b}$ & $41.3 \mathrm{c}$ \\
\hline & ReN3 & $55.9 \mathrm{c}$ & $101.5 \mathrm{bc}$ & $56.6 \mathrm{~b}$ & $42.8 \mathrm{c}$ \\
\hline & ReN4 & $49.3 \mathrm{c}$ & $86.9 \mathrm{~d}$ & $54.1 \mathrm{~b}$ & $50.5 \mathrm{~b}$ \\
\hline & CK & $55.1 \mathrm{c}$ & $98.9 \mathrm{c}$ & $46.7 \mathrm{c}$ & $43.7 \mathrm{c}$ \\
\hline \multirow{5}{*}{ Bulk soil } & ReN1 & $83.3 \mathrm{a}$ & $107.7 \mathrm{ab}$ & $57.8 \mathrm{ab}$ & $60.8 \mathrm{a}$ \\
\hline & ReN2 & $85.5 \mathrm{a}$ & $117.4 \mathrm{a}$ & $57.3 \mathrm{ab}$ & $45.6 \mathrm{bc}$ \\
\hline & ReN3 & $62.0 \mathrm{bc}$ & $113.3 \mathrm{ab}$ & $62.7 \mathrm{a}$ & $47.5 b c$ \\
\hline & ReN4 & $49.8 \mathrm{c}$ & $88.1 \mathrm{~cd}$ & $55.4 \mathrm{~b}$ & $51.7 \mathrm{~b}$ \\
\hline & CK & $65.8 \mathrm{bc}$ & $111.4 \mathrm{ab}$ & $61.6 \mathrm{a}$ & $55.1 \mathrm{a}$ \\
\hline
\end{tabular}

Note:

Different letters in the same row indicate significant differences $(\mathrm{p}<0.05 \%)$ among different treatments within a soil division (Data processing system 7.05 DMRT).

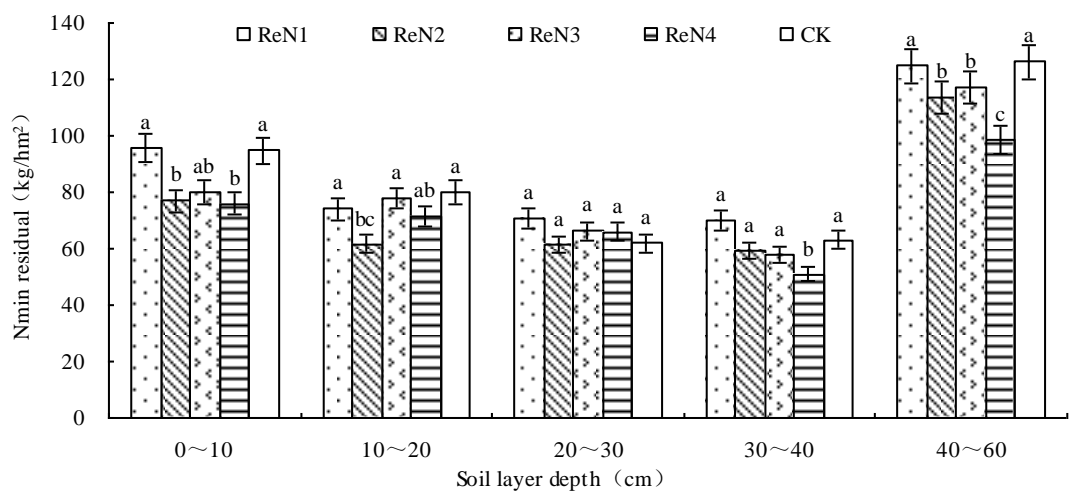

Fig. 1. Residual Nmin of soil layers under topdressing with RMW irrigation after post-harvest Different letters above the bars indicate significant differences $(\mathrm{p}<0.05 \%)$ at the same soil layer depth among different treatments (Data processing system 7.05DMRT.

\subsection{Tomato fruits quality with RMW irrigation}

Tomato fruit Vc content of N216 treatment was greater than that of N270, N189, N135 and CK. Compared with CK, tomato fruit Vc content of N270, N216, N189 and N135 was higher, by $11.35 \%, 26.04 \%, 8.18 \%$ and $5.11 \%$, respectively(Table 4). Tomato fruit organic acid content of N270, N216, N189, $\mathrm{N} 135$ and CK was $0.43 \%, 0.40 \%, 039 \%, 0.37 \%$ and $0.39 \%$, respectively. Compared with CK, tomato fruit organic acid content of N216, N189 and N135 was no significant difference(Table 4). Tomato fruit soluble proteins content of 
N270, N216, N189, N135 and CK was 6.84, 6.52, 5.99, 5.60 and $6.26 \mathrm{mg} / 100 \mathrm{~g}$, respectively. Compared with $\mathrm{CK}$, tomato fruit soluble proteins content of N270, N216 was greater by $9.26 \%$ and $4.15 \%$, respectively(Table 4). Tomato fruit soluble sugar content of N216 was higher than that of N189, N135, N270 and CK. Compared with CK, tomato fruit soluble sugar content of N270, N216, $\mathrm{N} 189$ and $\mathrm{N} 135$ was greater by $3.35 \%, 14.94 \%, 14.06 \%$ and $2.85 \%$, respectively(Table 4). Tomato fruit ratio of soluble sugar to organic acid of N270, N216, N189, N135 and CK was 6.50, 7.73, 7.98, 7.57 and 7.00, respectively. Compared with $\mathrm{CK}$, tomato fruit ratio of soluble sugar to organic acid of N216, N189, N135 was significant improved by $10.32 \%, 13.89 \%$ and $8.05 \%$, respectively(Table 4$)$.

Table 4. The Vc, soluble proteins, organic acids, soluble sugar content of tomato fruits with reclaimed municipal wastewater irrigation.

\begin{tabular}{llllll}
\hline Treatments & $\begin{array}{l}\text { VCl } \\
\left(\mathrm{mg} \cdot(100 \mathrm{~g} \mathrm{FW})^{-1}\right)\end{array}$ & $\begin{array}{l}\text { Soluble proteins/ } \\
\left(\mathrm{mg} \cdot(100 \mathrm{~g} \mathrm{FW})^{-1}\right)\end{array}$ & $\begin{array}{l}\text { Organic acids/ Soluble sugar/ } \\
(\%)\end{array}$ & $\begin{array}{l}\text { Ratio of sugar } \\
\text { to acid }\end{array}$ \\
\hline $\mathrm{N} 270$ & $15.14 \mathrm{a}$ & $6.84 \mathrm{a}$ & $0.43 \mathrm{a}$ & $3.42 \mathrm{a}$ & $6.50 \mathrm{c}$ \\
$\mathrm{N} 216$ & $17.13 \mathrm{a}$ & $6.52 \mathrm{a}$ & $0.40 \mathrm{~b}$ & $3.81 \mathrm{a}$ & $7.73 \mathrm{a}$ \\
$\mathrm{N} 189$ & $14.71 \mathrm{a}$ & $5.99 \mathrm{ab}$ & $0.39 \mathrm{~b}$ & $3.78 \mathrm{a}$ & $7.98 \mathrm{a}$ \\
$\mathrm{N} 135$ & $14.29 \mathrm{a}$ & $5.60 \mathrm{ab}$ & $0.37 \mathrm{bc}$ & $3.41 \mathrm{a}$ & $7.57 \mathrm{a}$ \\
$\mathrm{CK}$ & $13.59 \mathrm{a}$ & $6.26 \mathrm{ab}$ & $0.39 \mathrm{~b}$ & $3.31 \mathrm{a}$ & $7.00 \mathrm{~b}$ \\
\hline
\end{tabular}

\subsection{Nitrogen economy and yields with RMW irrigation}

The biomass of ReN2 was significantly higher than that of CK differing by $8.66 \%$, but significantly lower than that of ReN1 differing by $11.08 \%$. The tomato yield of ReN2 was significantly higher than that of ReN1, ReN3, ReN4 and CK differing by 9.91, 4.74, 9.20 and 9.38\%, respectively(Table 5). The nitrogen in plant and fruit of ReN2 was significantly higher than that of ReN3, ReN4 and CK differing by 46.62, 83.14 and $62.51 \%$, respectively. Partial factor productivity from applied $\mathrm{N}$ of ReN2 was significantly higher than that of ReN1 and CK differing by 21.18 and $20.59 \%$, respectively. Apparent nitrogen loss of ReN2 was significantly less than that of ReN1 and CK differing by 14.27 and $6.34 \%$, respectively. Nitrogen supplying capacity of ReN1, ReN2 and ReN3 were not significantly different but nitrogen supplying capacity of ReN1, ReN2 and ReN3 were significantly higher than that of ReN4 and CK differing from 6.82 to $11.68 \%$. Comparing with $\mathrm{CK}$, biomass, yield and nitrogen in fruit of RMW irrigation with suitable topdressing $\mathrm{N}$ treatment were significantly improved, resulting in higher partial factor productivity from applied $\mathrm{N}$ and nitrogen supplying capacity. The tomato plant biomass of ReN1 was significantly higher than that of ReN2 and ReN3, however, the ReN1 treatment resulted an increased growth of the tomato plants at the expense of tomato yield 
(Zhu et al. 2004). Thus, the yield of ReN2 and ReN3 was significantly higher than that of ReN1. Furthermore, partial factor productivity from applied $\mathrm{N}$ for ReN2 and ReN3 was improved when compared with ReN1, and nitrogen apparent loss for ReN2 and ReN3 was decreased (Elia et al. 2012). Obviously, the increase in tomato yield and improvement in the nitrogen supplying capacity of root layer could be achieved by reducing the topdressing applied $\mathrm{N}$ along with RMW irrigation.

Table 5. Tomato biomass, yield and soil nitrogen supplying capacity with reclaimed municipal wastewater irrigation.

\begin{tabular}{|c|c|c|c|c|c|c|c|c|c|}
\hline $\begin{array}{l}\text { Treat- } \\
\text { ments }\end{array}$ & $\begin{array}{r}\mathrm{Ni} \\
\text { rate/ } \\
\text { Base } \\
\text { ertilizer }\end{array}$ & $\begin{array}{l}\text { trogen } \\
\left(\mathrm{kg} / \mathrm{hm}^{2}\right) \\
\text { Topdressing }\end{array}$ & $\begin{array}{l}\text { Nitrogen } \\
\text { in } \\
\text { irrigation } \\
\text { g water } \\
\left(\mathrm{kg} / \mathrm{hm}^{2}\right)\end{array}$ & $\begin{array}{l}\text { Biomas؛ Yield } \\
\left(\mathrm{t} / \mathrm{hm}^{2}\right) \quad\left(\mathrm{t} / \mathrm{hm}^{2}\right)\end{array}$ & $\begin{array}{l}\text { Nitrogen } \\
\text { in plant } \\
\text { and fruit } \\
\left(\mathrm{kg} / \mathrm{hm}^{2}\right)\end{array}$ & $\begin{array}{l}\text { Nitrogen } \\
\text { in fruit } \\
\left(\mathrm{kg} / \mathrm{hm}^{2}\right)\end{array}$ & $\begin{array}{c}\mathrm{PFP}^{\mathrm{a}} \\
(\mathrm{kg} / \mathrm{kg})\end{array}$ & $\begin{array}{c}\mathrm{NAL}^{\mathrm{b}} \\
\left(\mathrm{kg} / \mathrm{hm}^{2}\right)\end{array}$ & $\begin{array}{c}\mathrm{NSC}^{\mathrm{c}} \\
\left(\mathrm{kg} / \mathrm{hm}^{2}\right)\end{array}$ \\
\hline ReN1 & 310.4 & 270 & 87.34 & $7.76 \mathrm{a} \quad 146.76 \mathrm{a}$ & 130 & $41.88 \mathrm{a}$ & 240 & 642 & $225.13 a$ \\
\hline ReN2 & 310.4 & 216 & 87.34 & $6.90 \mathrm{bc} 146.79 \mathrm{a}$ & $153.65 \mathrm{a}$ & $43.16 \mathrm{a}$ & 291 & 55 & $226.73 a$ \\
\hline ReN3 & 310.4 & 189 & 87.34 & $7.00 \mathrm{~b} \quad 122.64 \mathrm{~b}$ & $146.70 \mathrm{~b}$ & $29.43 b$ & $293.75 b$ & $543.01 \mathrm{c}$ & $222.27 \mathrm{a}$ \\
\hline ReN4 & 310.4 & 135 & 87.34 & $6.74 \mathrm{c} 112.58 \mathrm{bc}$ & $140.70 \mathrm{c}$ & $23.56 \mathrm{~d}$ & $315.89 a$ & $508.33 d$ & $203.02 b$ \\
\hline CK & 310.4 & 270 & 10.83 & $6.35 \mathrm{~d} \quad 109.10 \mathrm{c}$ & $140.48 \mathrm{c}$ & $26.56 \mathrm{c}$ & $242.05 \mathrm{c}$ & $587.86 \mathrm{~b}$ & $209.20 \mathrm{~b}$ \\
\hline
\end{tabular}

Note:

Values followed by different letters of the same column show significant differences $(\mathrm{p}<0.05)$ among treatments.

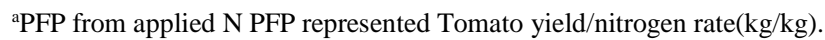

bNALrepresentedNmin residual of 0 to $30 \mathrm{~cm}$ root layer before the tomato transplant+ base fertilizer+ topdressing+ nitrogen in irrigation water-nitrogen in plant and fruit- Nmin residual of 0 to $30 \mathrm{~cm}$ root layer after the tomato post-harvest.

${ }^{\mathrm{c} N i t r o g e n}$ supplying capacity(NSC)representedNmin variation of 0 to $30 \mathrm{~cm}$ soil depth.

\section{Conclusions}

Our main findings are: (1) RMW irrigation lead to an average of $5.42-40.39 \%$, increase in mineral nitrogen of rhizosphere soil in 1st, 2nd and 4th cluster fruit expanding stage. (2) RMW irrigation could significantly improve the biomass and yield of tomato, and then the nitrogen in fruit, partial factor productivity from applied $\mathrm{N}$ and nitrogen supplying capacity. (3) RMW irrigation could significantly improve nitrogen supplying capacity by $8.38 \%$. (4) The ratio of soluble sugar to organic acid with RMW irrigation was improved than that of $\mathrm{CK}$, and Vc, soluble proteins with RMW irrigation has no significant difference.

\section{References}

1. J.B.McPherson, Land treatment of wastewater at Werribee: past, present and future. Prog. Water Technol. 1979, 11:15-31. 
2. Valentina L. Water reuse for irrigation: agriculture, landscapes, and turf grass. CPC press, 2005.

3. S.D. Lyu, W.P. Chen, W.L. Zhang, Y.P. Fan and W.T. Jiao, Wastewater reclamation and reuse in China: Opportunities and challenges. Journal of Environmental Sciences 2016, (39):86-96.

4. R. Aiello, G.L.CirelliandS.Consoli, Effects of reclaimed wastewater irrigation on soil and tomato fruits: A case study in Sicily (Italy). Agric. Water Manage.2007,93,(1-2): 65-72.

5. J.H.Guo, X.J.Liu, Y.Zhang, J.L.Shen, W.X.Han, W.F.Zhang, P.Christie, K.W.T.Goulding, P.M. Vitousek and F.S. Zhang, Significant Acidification in Major Chinese Croplands. Science 2010, 327(5968):1008-1010.

6. D.M. Chen, J.J. Li, Z.C. Lan and Y.F. Bai, Soil acidification exerts a greater control on soil respiration than soil nitrogen availability in grasslands subjected to long-term nitrogen enrichment. Functional Ecology 2016, 30, 658-669.

7. A. Shahalam, B.M. Abuzahra and A. Jaradat, Wastewater irrigation effect on soilcrop and environment: a pilot scale study at Irbid, Jordan. Water Air Soil Poll., 1998, 106, 425-445.

8. M.S. Fan, J.B. Shen, L.X. Yuan, R.F. Jiang, X.P. Chen, W.J. Davies and F.S.Zhang,Improving crop productivity and resource use efficiency to ensure food security and environmental quality in China. J. Exp. Botany2012,63(1): 13-24.

9. B. Grizzetti, P. Passy, G. Billen, F. Bouraoui, J. Garnier and L. Lassaletta, The role of water nitrogen retention in integrated nutrient management: assessment in a large basin using different modelling approaches. Environmental Research Letters 2015,10(6): 1-11.

10. Q. Chen, H.Y. Zhang, X.S. Zhang, X.L. Li and H.P. Liebig, Field application of $\mathrm{N}$-Expert system on $\mathrm{N}$ recommendation of autumn spinach. Acta Agric. Boreali-Sin. 2002, 17(4):128-134.(in Chinese)

11. E.L. Clawson, H.J. Mascagni, G.A. Breitenbeck, D.J. Boquet, J.F. Liscano, K.S. McCarter, Winter crops as bioassays of soil nitrogen supplying capacity. Journal of Plant Nutrition 2011, 34(6): 861-876.

12. Y. Zhao, X.J. Zhang, J.H. Luo, Effect of fertilization on nitrogen leaching loss from soil and nutrients utilization by tomato and cucumber in greenhouse. Plant Nutr. Fert. Sci. 2011, 17(2): 374-383.(in Chinese)

13. J. Yao, W.M. Shi, W.F. Xu, Effects of salt stress on expression of nitrate transporter and assimilation-related genes in tomato roots. Russian Journal of Plant Physiology 2008, 55(2):232-240

14. A.M. Palese, V. Pasquale, G. Celano, G. Figliuolo, S. Masi and C. Xiloyannis, Irrigation of olive groves in Southern Italy with treated 
municipal wastewater: Effects on microbiological quality of soil and fruits. Agric.Ecosyst. Environ. 2009 129(1-3): 43-51.

15. Z. Chen, H.H. Ngo and W.S. Guo, A critical review on sustainability assessment of recycled water schemes. Sci. Tot. Env. 2012, 426: 13-31.

16. Q. Zhao, D.H. Zeng and Z.P. Fan, Nitrogen and phosphorus transformations in the rhizospheres of three tree species in a nutrient-poor sandy soil. Appl. Soil Ecol. 2010, 46(3): 341-346.

17. B.F.F. Pereira, Z.L. He, P.J. Stoffella and A.J. Melfi, Reclaimed wastewater: Effects on citrus nutrition. Agr. Water Manage. 2011, 98(12): 1828-1833.

18. J.H. Zhu, X.L. Li, F.S. Zhang, J.L. Li and P. Christie, Responses of greenhouse tomato and yields and nitrogen dynamics to applied compound fertilizers . Pedosphere 2004, 14(2): 213- 222.

19. A. Elia and G. Conversa, Agronomic and physiological responses of a tomato crop to nitrogen input. Eur.J.Agron. 2012, 40: 64- 74. 